\title{
Antinociceptive activities of crude methanolic extract and phases, $n$-butanolic, chloroformic and ethyl acetate from Caulerpa racemosa (Caulerpaceae)
}

\author{
Everton T. Souza, ${ }^{1}$ Aline C de Queiroz, ${ }^{1}$ George Emmanuel C. de Miranda, ${ }^{2}$ \\ Vitor P. Lorenzo, ${ }^{3}$ Evandro F da Silva, ${ }^{3}$ Thays L. M. Freire-Dias, ${ }^{1}$ \\ Yolanda K. Cupertino-Silva, ${ }^{1}$ Gabriela Muniz de A. Melo, ${ }^{1}$ Bárbara V. O. Santos, ${ }^{3}$ \\ Maria Célia de O. Chaves, ${ }^{3}$ Magna S. Alexandre-Moreira ${ }^{*, 1}$ \\ ${ }^{1}$ Laboratório de Farmacologia e Imunidade, Instituto de Ciências Biológicas e da Saúde, Universidade Federal \\ de Alagoas, Praça Afrânio Jorge, s/n, 57020-720 Maceió-AL, Brazil, \\ ${ }^{2}$ Laboratório de Algas Marinhas, Departamento de Sistemática e Ecologia, Universidade Federal da Paraíba, \\ 58051-970 João Pessoa-PB, Brazil, \\ ${ }^{3}$ Laboratório de Tecnologia Farmacêutica, Universidade Federal da Paraíba, Caixa Postal 5009, 58051-000 \\ João Pessoa-PB, Brazil
}

\begin{abstract}
RESUMO: "Atividade antinociceptiva do extrato metanólico bruto e das fases $\boldsymbol{n}$-butanólica, clorofórmica e acetato de etila de Caulerpa recemosa (Caulerpaceae)". Neste estudo, tentamos identificar a atividade antinociceptiva do extrato metanólico bruto e das fases $n$-butanólica, clorofórmica e acetato de etila provenientes da alga Caulerpa racemosa. Esta alga é cosmopolita no mundo, principalmente em regiões tropicais. O extrato metanólico bruto e as fases n-butanólica, clorofórmica e acetato de etila foram administrados por via oral, na concentração de $100 \mathrm{mg} /$ $\mathrm{kg}$. Estes foram capazes de reduzir a nocicepção produzida pelo ácido acético, sendo 47,39\%, $70,51 \%, 76,11 \%$ e $72,24 \%$, respectivamente. No ensaio da placa quente as fases clorofórmica e acetato de etila foram ativas neste modelo. Na fase neurogênica do teste de formalina, foi observado que o extrato metanólico bruto $(51,77 \%)$, fase $n$-butanólica $(35,12 \%)$, fase clorofórmica $(32,70 \%)$ e indometacina $(32,06 \%)$ foram eficazes em inibir a resposta nociceptiva. $\mathrm{Na}$ fase inflamatória, apenas a fase acetato de etila $(75,43 \%)$ e indometacina $(47,83 \%)$ foram capazes de inibir significativamente a resposta nociceptiva. Com base nestes dados, podemos sugerir que o a fase acetato de etila apresenta um significativo efeito anti-inflamatório, cuja potência ainda não foi determinada. No entanto, estudos farmacológicos e químicos serão necessários, a fim de caracterizar o mecanismo responsável pela ação antinociceptiva e também para identificar outros princípios ativos presentes na alga Caulerpa racemosa.
\end{abstract}

Unitermos: Caulerpa racemosa, Caulerpaceae, antinociceptivo, anti-inflamatório, alga.

\begin{abstract}
In this study, we attempted to identify the possible antinociceptive actions of $n$-butanolic phase, chloroformic phase, ethyl acetate phase and crude methanolic extract obtained from Caulerpa racemosa. This seaweed is cosmopolitan in world, mainly in tropical regions. The $n$-butanolic, chloroformic, ethyl acetate phases and crude methanolic extract, all administered orally in the concentration of $100 \mathrm{mg} / \mathrm{kg}$, reduced the nociception produced by acetic acid by $47.39 \%, 70.51 \%, 76.11 \%$ and $72.24 \%$, respectively. In the hotplate test the chloroformic and ethyl acetate phase were activite in this models. In the neurogenic phase on formalin test, were observed that crude methanolic extract $(51.77 \%), n$-butanolic phase $(35.12 \%)$, chloroformic phase $(32.70 \%)$ and indomethacin $(32.06 \%)$ were effective in inhibit the nociceptive response. In the inflammatory phase, only the ethyl acetate phase $(75.43 \%)$ and indomethacin $(47.83 \%)$ inhibited significantly the nociceptive response. Based on these data, we can infer that the ethyl acetate phase shows a significant anti-inflammatory profile, whose power has not yet been determined. However, pharmacological and chemical studies are continuing in order to characterize the mechanism(s) responsible for the antinociceptive action and also to identify other active principles present in Caulerpa racemosa.
\end{abstract}

Keywords: Caulerpa racemosa, Caulerpaceae, antinociceptive, anti-inflammatory, seaweed. 


\section{INTRODUCTION}

Marine organisms represent a valuable source of new compounds. The biodiversity of the marine environment and the associated chemical diversity constitute a practically unlimited resource of new active substances in the field of the development of bioactive products. The marine pharmacy currently holds more than 35,000 marine-derived biological samples, with approximately 150 compounds to be cytotoxic against the tumor cells (Arif et al., 2004). It was also observed a large increase of studies about the antiinflammatory pharmacology of the marine compounds, such as astaxanthin, bolinaquinone, cacospongionolide B, clathriol B, conicamin, cycloamphilectene 2, elisabethadione, plakohypaphorine, pourewic acid $\mathrm{A}$, methylpourewate $\mathrm{B}$, cadlinolide $\mathrm{C}$, petrocortyne A, petrosaspongiolides $\mathrm{M}-\mathrm{R}$, pseudopterosin $\mathrm{N}$, pseudopterosin R, seco-pseudopterosin E (Mayer et al., 2007).

In Brazil, research in natural products of marine origin has been initiated for more than 30 years, according Kelecom (1997), however it is still incipient. Although the Brazilian coast is the second largest in the world, after Australia, with approximately 8,000 $\mathrm{km}$ in length, the development of chemistry of natural products from marine organisms in Brazil has been neglected for many years, because the main focus of the chemistry of natural products Brazil was directed to the study of plants (Berlinck et al., 2004). Thus, the Brazilian marine fauna and flora remain unexplored regarding bioprospecting for active natural products.

The macroscopic marine algae have attracted the attention of the scientific community for the great potential as producers of chemicals, medical and pharmacological interest (Mayer and Hamann, 2004, 2005; Blunt et al., 2005; Dresch et al., 2005; Lhullier et al., 2006; Mayer et al., 2007; Rocha et al., 2007; Seleghim et al., 2007; Rozas \& Freitas, 2008a,b). To date, more than 2,400 natural products have been isolated from algae, especially the divisions rhodophytes (red algae), pheophytes (brown algae or brown) and chlorophytes (green algae), and most of them, from tropical and subtropical populations. In general, algae synthesize lipophilic non-polar secondary metabolites such as terpenoids and acetogeninas as compounds of mixed biosynthesis occur in low concentrations. Polar polyphenols may occur in high concentrations (Pereira et al., 2003).

Caulerpa racemosa (Forsskal) J. Agardh (Caulerpaceae), a pan-tropical to temperate-warm water species widely distributed throughout the world, is a green alga (Bryopsidales) that was collected for the first time in 1926 in the Mediterranean Sea by Hamel in the Sousse harbour, Tunisia (Verlaque et al., 2000; Piazzi et al., 2001). This seaweed has a number of pharmacological activities described in the literature, among which we mention: antitumor (Cavas et al., 2006), anti-viral (Ghosh et al., 2004; Chattopadhyay et al., 2007) and antioxidant (Cavas and Yurdakoc, 2005). However, up to date there are a few investigations supporting the pharmacological properties of this seaweed.

As the seaweed up an important biological source as biologically active natural products and structurally unusual and few studies conducted with this purpose, mainly in Brazil, then this study was intended to evaluate the antinociceptive and anti-inflammatory activities of $n$-butanolic phase, chloroformic phase, ethyl acetate phase and crude methanolic extract from C. racemosa in nociceptive animal models.

\section{MATERIAL AND METHODS}

\section{Marine material}

Seaweed C. racemosa (Forsskal) J. Agardh was collected of the coastal region of Bessa $\left(7^{\circ} 03^{\prime} 52^{\prime \prime} \mathrm{S}\right.$ ( 34 ${ }^{\circ} 49^{\prime} 51^{\prime \prime}$ ), João Pessoa, State of Paraiba, Brazil in April 2008. The specimen was identified by Dr George Emmanuel Cavalcanti de Miranda. A voucher specimen (JPB 13999) has been deposited at the Herbarium Lauro Pires Xavier of the Universidade Federal da Paraíba, Brazil.

\section{Extraction and fractionation}

The fresh sample of C. racemosa (5.4 kg) was exhaustively extracted with $\mathrm{MeOH}$ at room temperature. The solvent was removed under reduced pressure at $<40$ ${ }^{\circ} \mathrm{C}$, a dark green residue was obtained. Part of the crude methanol extract was submitted to solid-liquid partition successively with hexane, chloroform, ethyl acetate and $n$-butanol. The solutions produced were evaporated under reduced pressure producing the hexane $(0.13$ $\mathrm{g})$, chloroformic (3.58 g), ethyl acetate (1.53 g) and $n$-butanolic $(3.53 \mathrm{~g})$ phases. Chloroformic, ethyl acetate and $n$-butanolic phase and crude methanolic extract were separated to be evaluated for their analgesic and antiinflammatory activities. Hexane phase did not present sufficient quantity to perform the pharmacological tests.

\section{Biological activity tests}

\section{Drugs and reagents}

Acetic acid and indomethacin (Merck), arabic gum and dipyrone (Sigma Chemical), and morphine sulphate (Dimorf-Cristalia-BR) were purchased from commercial sources. A solution of formalin $2.5 \%$ was prepared with formaldehyde (from Merck) in saline $(\mathrm{NaCl} 0.9 \%)$. The marine material was used as suspension in arabic gum in all the experiments. 


\section{Animals}

Adult male and female Swiss albino mice (20$35 \mathrm{~g})$ were used in the experiments. They were housed in single-sex cages under a 12-h light:12 h dark cycle (lights on at $6 \mathrm{~h}$ ) in a controlled temperature room $(22$ $\left.\pm 2{ }^{\circ} \mathrm{C}\right)$. They had free access to food and water. Groups of 6-8 animals were used in each test group and control animals received vehicle only. The experiments were performed after the approval of the protocol by the local Institutional Ethics Committee. All experiments were carried out in accordance with the current guidelines for the care of laboratory animals and the ethical guidelines for investigations of experimental pain in conscious animals (Zimmermann, 1983).

\section{Writhing test}

The methods described by Koster et al. (1959) were used with few modifications. In brief, the selected groups of animals, consisting of six mice per dose of phases, extracts or drug, were used in the test. Animals were pretreated (60 min before acid acetic injection) with $n$-butanolic phase, chloroformic phase, ethyl acetate phase and crude methanolic extract (all at the dose $100 \mathrm{mg} / \mathrm{kg}$, body wt., p.o). Positive control mice groups received standard analgesics for comparison, dipyrone $60 \mathrm{~min}$ prior to the i.p. injection of acetic acid $0.6 \%(0.25 \mathrm{~mL})$. The negative control animals not received anything prior to the i.p. injection of acetic acid. Five minutes after the i.p. injection of acetic acid, the number of writhing exhibited by each mouse was counted for $20 \mathrm{~min}$. The antinociceptive activity was expressed as the reduction on the number of abdominal writhing.

\section{Hot-plate test}

The hot plate test was used to measure response latency according to the method described by Eddy and Leimbach (1953), with minor modifications. In these experiments, the hot plate apparatus (Ugo Basile, Model-DS 37) was maintained at $55.5 \pm 1{ }^{\circ} \mathrm{C}$. Animals were placed on the heated surface and the time between placement and licking of the paws or jumping was recorded as latency. Latency was recorded for vehicle control groups $(10 \mathrm{~mL} / \mathrm{kg})$ or pre-treated groups with $n$-butanolic phase, chloroformic phase and ethyl acetate phase (all at the dose $100 \mathrm{mg} / \mathrm{kg}$, p.o.) or morphine (15 $\mu \mathrm{mol} / \mathrm{kg}$, body wt., i.p). The test compounds were administered after animal selection on time of $30 \mathrm{~min}$. The selection was made on the basis of the reactivity on the test. Pre-treatment times 0 and $30 \mathrm{~min}$ were used for assay adaptation and selection of the animals, respectively. Only mice showing a reaction time within the range of 4-10 sec. were used in this test. The latency of the reaction to nociception was measured at time 0 and then at $30 \mathrm{~min}$ intervals up to the 180 th $\min$. The phases and the extrats were administered at time $30 \mathrm{~min}$ and treatment latencies were recorded at times 60, 90, 120 and $150 \mathrm{~min}$.

\section{Formalin-induced nociception in mice}

The formalin test was performed according to the method of Hunskaar and Hole (1987). Briefly, 20 $\mu 1$ of a $2,5 \%(\mathrm{v} / \mathrm{v})$ solution of formalin in saline was injected into the sub plantar region of the right hind paw and the quantification of the time that the animal spent licking the right hind paw during the first 5 min (first phase) and from 15 to $30 \mathrm{~min}$ (second phase) of postinjection time was performed. The test was performed at ambient temperature of $22-26^{\circ} \mathrm{C}$ and care was taken to exclude environmental disturbances (high temperature, noise and excessive movement) that might interfere with the animal's response (Tjolsen and Hole, 1997).

\section{Statistical analysis}

Data obtained from animal experiments were expressed as the mean standard error (Mean \pm S.E.M.). Statistical differences between the treated and the control groups were evaluated by ANOVA and Dunnett hoc tests. $P<0.05$ was considered to be significant ( ${ }^{*} P$ $<0.05 ; * * P<0.01)$.

\section{RESULTS}

\section{Writhing test}

The results depicted in Figure 1 show that the crude methanolic extract and $n$-butanolic, chloroformic and ethyl acetate phase from $C$. racemosa, given 40 min beforehand, produced an inhibition of acetic acidinduced abdominal constrictions in mice. The treatment of mice with crude methanolic extract, $n$-butanolic phase, chloroformic phase and ethyl acetate phase (all at the dose $100 \mathrm{mg} / \mathrm{kg}$, p.o) produced marked inhibition of acetic acid induced writhing response. The inhibitions were $72.24 \%, 47.39 \%, 70.51 \%$ and $76.11 \%$ respectively.

\section{Hot-plate test}

The results in Figure 2 show that the treatment of animals with morphine $(15 \mu \mathrm{mol} / \mathrm{kg}$, i.p.) induced a marked increase in the latency of the animals at all the reading $(60,90,120$ and $150 \mathrm{~min})$. Moreover, the chlorofomic phase (at the $150 \mathrm{~min}$ ) and ethyl acetate phase (at 90 and $120 \mathrm{~min}$ ) increased the latency time of response in animal model of plate, suggesting a supraspinal activity to these phases.

Formalin-induced nociception in mice 
In assessing the antinociceptive and antiinflammatory activity in this teste of nociception induced by formalin depicted in Figures 3A and $3 \mathrm{~B}$, the antinociceptive activity was observed in the neurogenic phase to the crude methanolic extract (51.77\%, $n$-butanolic phase $(35.12 \%)$, Chloroformic phase $(32.70 \%)$ and indomethacin $(32.06 \%)$, exception to ethyl acetate phase. In the inflammatory phase only the ethyl acetate phase $(75.43 \%)$ and indomethacin $(47.83 \%)$ induced significant inhibition of response in this model. From these data can be suggested that the crude methanol extract, $n$-butanolic phase, and phase Chloroformic presents a profile antinociceptive while the ethyl acetate phase presents an anti-inflammatory profile whose power has not been determined yet.

\section{DISCUSSION}

The antinociceptive activities of $n$-butanolic phase, chloroformic phase, ethyl acetate phase and crude methanolic extract from C. racemosa, all givem orally at the concentration $100 \mathrm{mg} / \mathrm{kg}$, were evaluated using chemical (acetic acid and formalin) and thermal (hot plate test) stimuli. Methods for investigating antinociception were selected so that both the central and peripheral activity were investigated. The acetic acidinduced abdominal constriction and hot-plate methods elucidated peripheral and central activity, respectively, while the formalin test investigated both.

The acetic acid-induced writhing model is normally used to study the peripheral antinociceptive effects of drugs. This method is simple and reliable, and affords rapid evaluation of peripheral analgesic action (Amendoeira et al., 2005). The extract and phases of C. racemosa tested in this study showed significant effect on this viscero-somatic model (tonic pain) reflected in a significant reduction of the acetic acidinduced abdominal writhing. The acetic acid- induced abdominal writhing involves the production and release of arachidonic acid metabolites via cycloxygenase (COX) and prostaglandin biosynthesis (Dongmo et al., 2005). However, this test is a nonspecific model (e.g. anticholinergic, tricyclic antidepressants and antihistaminic and other agents show activity in this test) it is widely used for analgesic screening and involves local peritoneal receptors (cholinergic and histaminic receptor) and the mediators acetylcholine and histamine (Alexandre-Moreira et al., 1999; Miranda et al., 2001). Thus, the $n$-butanol phase, chloroformic phase, ethyl acetate phase crude methanol extract from C. racemosa may be modulated the nociception by any of these mechanisms above.

The hot plate test is a central pain model that has a selectivity for painkillers such as morphine and other centrally active drugs. And the method has several advantages, particularly the strong sensitivity to pain and limited tissue damage (Deraedt et al., 1980). The heat induces an effect of termonociceptive skin and the integration of stimulus is due to stimulation of myelinated $\mathrm{C}$ fibers not driving slow (Hendry et al., 1999). The point is that the chloroformic and ethyl acetate phases increase the latency time of response in animal model of hot plate, and shows that these phases showed activity of supra-spinal analgesia.

To better assess the antinociceptive profile, extracts and phases were subjected to the test of nociception induced by formalin. This test is characterized by two phases: the first phase which is characterized by intense neurogenic pain immediately after injection and seems to be caused by stimulation of C-fibers after peripheral stimulation (direct stimulation of nociceptors). For a period there is a reduction of nociceptive activity (Hunskaar and Hole, 1987). The second phase appears to be caused by tissue and functional changes in dorsal horn and the caudal spine and is accompanied by release of inflammatory mediators and cannot be interpreted as a consequence of the first phase. It also originates from peripheral mechanisms and appears to be mediated from central sensory neurons due to peripheral inflammation as well as the activation of primary afferent neurons. For this reason the formalin test is used to evaluate the analgesic activity of substances, and also elucidate the mechanisms of analgesia in the first (neurogenic) and the second (inflammatory) phase (Hunskaar and Hole, 1987).

It has been well documented that several inflammatory mediators such as substance $\mathrm{P}$ and bradykinin participate in the manifestation of the response in the first phase (Shibata et al., 1989), where prostaglandins (Hunskaar and Hole, 1987; Shibata et al., 1989), serotonin, histamine and cinines are involved in the response of the second phase of formalin test (Tjolsen and Hole, 1997). In assessing the antinociceptive and antiinflammatory activity in the test of hyperalgesia induced by formalin (Figure 3), activity was observed in the neurogenic phase of crude methanolic extract and its phases, with the exception of ethyl acetate phase. In the inflammatory phase only the ethyl acetate phase and indomethacin induced significant inhibition of response in this model. From these data it can be suggested that the ethyl acetate phase has shown a significant antiinflammatory profile.

\section{CONCLUSION}

In conclusion, this study has shown that the crude methanolic extract and phases from C. racemosa possess significant antinociceptive effect in animals models, administrated by oral route. Moreover, pharmacological studies are continuing in order to characterize the mechanism(s) responsible for the antinociceptive action. Further studies are being conducted to isolate, characterize and evaluate the antinociceptive activity of 


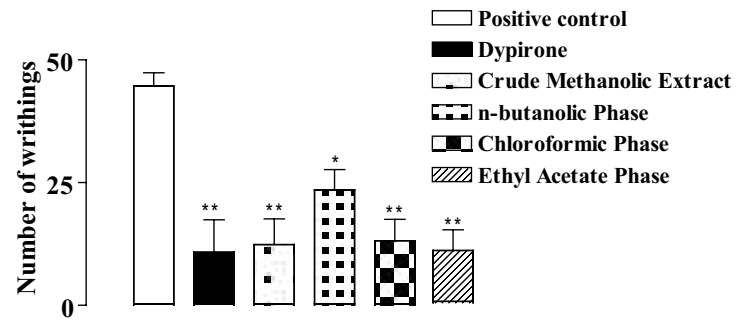

Figure 1. Antinociceptive effect of $n$-butanolic phase, chloroformic phase, ethyl acetate phase, crude methanolic extract (all at the dose $100 \mathrm{mg} / \mathrm{kg}$ ) and dypirone $(100 \mu \mathrm{mol} /$ $\mathrm{kg}$ ) on the acetic acid-induced writhings in mice. Each column represents the mean \pm sem of 6-8 animals. The asterisks denote the significance levels in comparison with control groups, $* P$ $<0.05, * * P<0.01$.

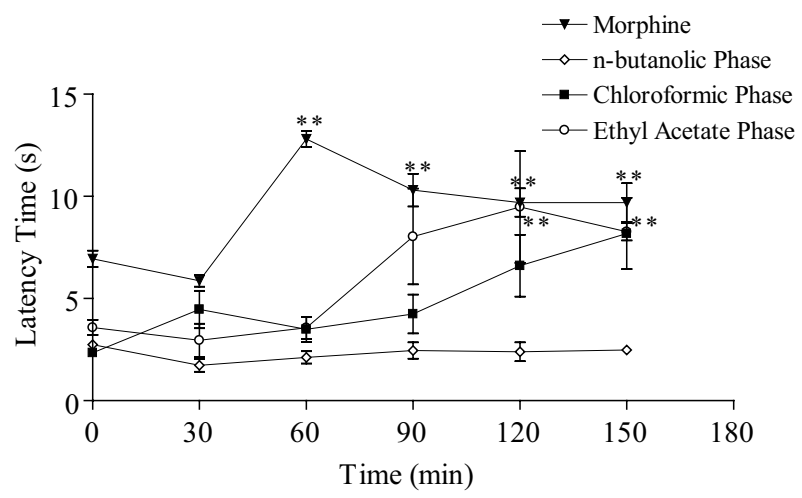

Figure 2. Time-course of the effects of $n$-butanolic phase, chloroformic phase, ethyl acetate phase (all at the dose 100 $\mathrm{mg} / \mathrm{kg}$, p.o.) and morphine $(15 \mu \mathrm{mol} / \mathrm{kg}$, s.c.) on thermal nociception. Each point represents the mean \pm sem of $6-8$ animals. The asterisks denote the significance levels in comparison with control groups, $* * P<0.01$.

(A) Neurogenic Phase

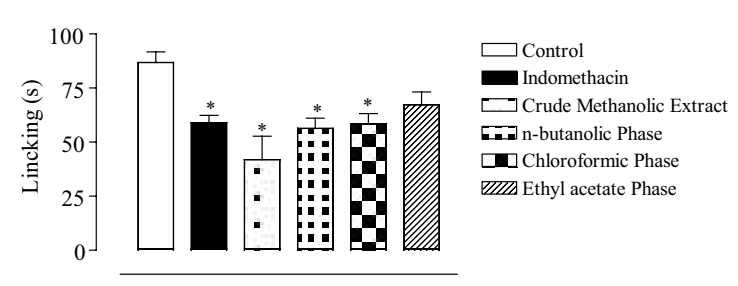

(B) Inflammatory Phase

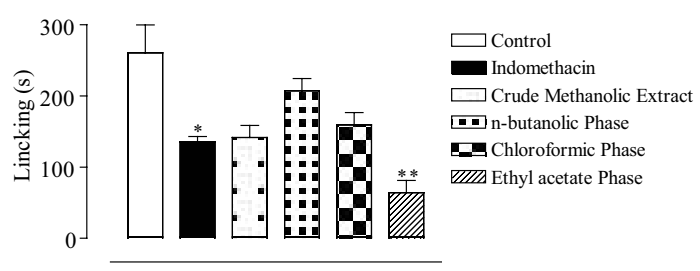

Figure 3. Antinociceptive of $n$-butanolic phase, chloroformic phase, ethyl acetate phase, crude methanolic extract (all at the dose $100 \mathrm{mg} / \mathrm{kg})$ and indomethacin $(100 \mu \mathrm{mol} / \mathrm{kg})$, against the early-phase (0-5 min, panel A) or late-phase (15-30 min, panel B) of formalin-induced nociception in mice. Each column represents the mean \pm sem of 6-8 animals. The asterisks denote the significance levels in comparison with control groups, $* P<0.05, * * P<0.01$. constituents from $n$-butanolic, chloroform and acetate phase, which may be responsible for antincceptive activity described in this work. Furthermore, this work shows for the first time the antinociceptive activity of the seaweed C. racemosa.

\section{ACKNOWLEDGEMENTS}

The authors are grateful to Conselho Nacional de Desenvolvimento Científico e Tecnológico (CNPq Edict 10/2006-Algas Marinha), to Ministry of Environment (License MMA/CGEN 18/2007) and the Ministry of Science and Technology (MCT) from Brazil for the joint funding of this research project. The authors wish to thank several of their colleagues working at the Universidade Federal de Alagoas and Universidade Federal da Paraíba for their constructive criticism and assistance in carrying out this project.

\section{REFERENCES}

Alexandre-Moreira MS, Piuvezam MR, Araújo CC, Thomas G 1999. Studies on the anti-inflammatory and analgesic activity of Curatella americana L. J Ethnopharmacol 67: 171-177.

Amendoeira FC, Frutuoso VS, Chedier LM, Pearman AT, Figueiredo MR, Kaplan MAC, Prescott SM, Bozza PT, Castro-Faria-Neto HC 2005. Antinociceptive effect of Nidularium procerum: a Bromeliaceae from the Brazilian coastal rain forest. Phytomedicine 12: 78-87.

Arif JM, Al-Hazzani AA, Kunhi M, Al-Khodairy F 2004. Novel marine compounds: anticancer or genotoxic? J Biomed Biotechnol 2: 93-98.

Berlinck RGS, Hajdu E, Rocha RM, Oliveira JHHL, Hernandez ILC, Seleghim MHR, Granato AC, Almeida EVR, Nunez CV, Muricy G, Peixinho S, Pessoa C, Moraes MO, Cavalcanti BC, Nascimento GGF, Thiemann O, Silva M, Souza AO, Silva CL, Mirarini PRR 2004. Challenges and rewards of research in marine natural products chemistry in Brazil. J Nat Prod 67: 510522.

Blunt JW, Copp BR, Munro MHG, Northcote PT, Prinsep MR 2005 Marine natural products. Nat Prod Rep 22: 1561.

Cavas L, Yurdakoc K 2005. An investigation on the antioxidant status of the invasive alga C. racemosa var. cylindracea (Sonder) Verlaque, Huisman, et Boudouresque (Caulerpales, Chlorophyta). J Exp Mar Biol Ecol 325: 189-200.

Cavas L, Baskin Y, Yurdakoc K, Olgun N 2006. Antiproliferative and newly attributed apoptotic activities from an invasive marine alga: $C$. racemosa var. cylindracea. J Exp Mar Biol Ecol 339: 111-119.

Chattopadhyay K, Adhikari U, Lerouge P, Ray B 2007. Polysaccharides from C. racemosa: Purification and structural features. Carbohydr Polymer 68: 407-441.

Deraedt R, Jouquey S, Delevallee F, Falahaut M 1980. Release of prostaglandins $\mathrm{E}$ and $\mathrm{F}$ in an algogenic reaction and its inhibition. Eur J Pharmacol 61: 17-24. 
Dongmo AB, Nguelefack T, Lacaille-Dubois MA 2005. Antinociceptive and anti-inflammatory activities of Acacia pennata wild (Mimosaceae). J Ethnopharmacol 98: 201-206.

Dresch RR, Haeser AS, Lerner C, Mothes B, Vozári-Hampe MM, Henriques AT 2005. detecção de atividade lectínica e atividade hemolítica em extratos de esponjas (Porifera) nativas da costa atlântica do Brasil. Rev Bras Farmacogn 15: 16-22.

Eddy NB, Leimbach D 1953. Synthetic analgesics II: Dithienylbutenyland dithienylbutylamines. $J$ Pharmacol Exp Ther 107: 385-393.

Ghosh P, Adhikari U, Ghosal PK, Pujol CA, Carlucci MJ, Damonte EB, Ray B 2004. In vitro anti-herpetic activity of sulfated polysaccharide fractions from Caulerpa racemos. Phytochemistry 65: 3151-3157.

Hendry SHC, Hsiao SS, Bushnell MC 1999. Somatic sensation. In: Zigmond MJ, Bloom FE, Roberts JL, Squire LR, Fundamental Neuroscience. Academic Press, London, pp. 768-769.

Hunskaar S, Hole K 1987. The formalin test in mice: dissociation between inflammatory and noninflammatory pain. Pain 30: 103-114

Kelecom A 1997. Marine natural products in Brazil. Isolation and structure determination. Cienc Cult 49: 321-330.

Koster R, Anderson M, De-Beer EJ 1959. Acetic acid analgesic screen. PNAS 18: 418-420.

Lhullier C, Horta PA, Falkenberg M 2006. Avaliação de extratos de macroalgas bênticas do litoral catarinense utilizando o teste de letalidade para Artemia salina. Rev Bras Farmacogn 16: 158-163.

Mayer AMS, Hamann MT 2004. Marine pharmacology in 2000: marine compounds with antibacterial, anticoagulant, antifungal, antiinflammatory, antimalarial, antiplatelet, antituberculosis, and antiviral activities, affecting the cardiovascular, immune, and nervous system and other miscellaneous mechanisms of action. Mar Biotechnol 6: 37-52.

Mayer AMS, Hamann MT 2005 Marine pharmacology in 2001-2002: marine compoundswith anthelmintic, antibacterial, anticoagulant, antidiabetic, antifungal, antiinflammatory, antimalarial, antiplatelet, antiprotozoal, antituberculosis, and antiviral activities; affecting the cardiovascular, immune and nervous systems and other miscellaneous mechanisms of action. Comp Biochem Physiol C Toxicol Pharmacol 140: 265-286.

Mayer AMS, RodriguezAD, Berlinck RGS, Hamann MT 2007. Marine pharmacology in 2003-4: Marine compounds with anthelminthic, antibacterial, anticoagulant, antifungal, antiinflammatory,antimalarial, antiplatelet, antiprotozoal, antituberculosis, and antiviral activities; affecting the cardiovascular, immune and nervous systems, and other miscellaneous mechanisms of action. Comp Biochem Physiol C Toxicol Pharmacol. 145: 553-581.

Miranda FGG, Vilar JC, Alves IAN, Cavalcanti SCH, Antoniolli AR 2001. Antinociceptive and antiedematogenic properties and acute toxicity of Tabebuia avellanedae Lor. ex Griseb. inner bark aqueous extract. BMC Pharmacol 1: 6.

Pereira RC, Da Gama BAP, Teixeira VL, Yoneshigue-Valentin Y 2003. Ecological roles of natural products of the
Brazilian red seaweed Laurencia obtusa. Braz J Med Biol Res 63: 665-672.

Piazzi L, Ceccherelli G, Cinelli F 2001. Threat to macroalgal diversity: effects of the introduced green alga $C$. racemosa in the Mediterranean. Mar Ecol Prog Ser 210: 149-159.

Rocha FD, Pereira RC, Kaplan MAC, Teixeira VL 2007. Produtos naturais de algas marinhas e seu potencial antioxidante. Rev Bras Farmacogn 17: 631-639.

Rozas EE, Freitas JC 2008a. Intracellular increase of glutamate in neuroblatoma cells induced by polar substances of Galaxaura marginata (Rhodophyta, Nemaliales). Rev Bras Farmacogn 18: 53-62.

Rozas EE, Freitas JC 2008b. Neurotoxins in the polar fraction of the seaweed Galaxaura marginata (Rhodophyta, Nemaliales). Rev Bras Farmacogn 18: 160-164.

Seleghim MHR, Lira SP, Kossuga MH, Batista T, Berlinck RGS, Hajdu E, Muricy G, Rocha RM, Nascimento GGF, Silva M, Pimenta EF, Thiemann OH, Oliva G, Cavalcanti BC, Pessoa C, Moraes MO, Galetti FCS, Silva CL, Souza AO, Peixinho S 2007. Antibiotic, cytotoxic and enzyme inhibitory activity of crude extracts from Brazilian marine invertebrates. Rev Bras Farmacogn 17: 287-318.

Shibata M, Ohkubo T, Takahashi H, Inuki R 1989. Modified formalin test: characteristic biphasic pain response. Pain 38: 347-352.

Tjolsen A, Hole K 1997. Animal models of analgesia. In: Dickenson A, Besson J. The Pharmacology of Pain. Berlin: Springer Verlag, p.1-20.

Verlaque M, Boudouresque CF, Meinesz A, Gravez V 2000. The $C$. racemosa complex (Caulerpales, Ulvophyceae) in the Mediterranean Sea. Bot Mar 43: 49-68.

Zimmermann M 1983. Ethical guidelines for investigation of experimental pain in conscious animals. Pain 16: 109-110. 